\title{
Photosynthesis and biomass allocation of cotton as affected by deep-layer water and fertilizer application depth
}

\author{
Z.K. CHEN*, Y.P. NIU*, H. MA*, A. HAFEEZ ${ }^{* *}$, H.H. LUO ${ }^{*}$, , and W.F. ZHANG* \\ Key Laboratory of Oasis Eco-Agriculture, Xinjiang Production and Construction Group, Shihezi University, \\ 832003 Shihezi, Xinjiang, China* \\ Cotton Physiology Lab for Efficient Production, College of Plant Science and Technology, Huazhong \\ Agricultural University, 430070 Wuhan, Hubei, China**
}

\begin{abstract}
Available water stored in deep soil layers could increase the photosynthetic capacity of cotton. It was hypothesized that the photosynthesis of cotton would be enhanced by changing the fertilizer application depth under different deep-layer water conditions. We examined two deep-layer water levels, i.e., well-watered $\left(\mathrm{W}_{80}\right)$ and not watered $\left(\mathrm{W}_{0}\right)$, combined with surface application $\left(\mathrm{F}_{10}\right)$ and deep application $\left(\mathrm{F}_{30}\right)$ of basal fertilizer. Compared to $\mathrm{W}_{0}, \mathrm{~W}_{80}$ resulted in increased leaf area (LA), photosynthetic pigment contents, maximal PSII efficiency $\left(\mathrm{F}_{\mathrm{v}} / \mathrm{F}_{\mathrm{m}}\right)$, effective quantum yield of PSII (Y $\left.\mathrm{Y}_{\mathrm{II}}\right)$ and PSI $\left(\mathrm{Y}_{\mathrm{I}}\right)$, electron transport rate of PSII (ETR $\mathrm{EII}_{\mathrm{II}}$ and PSI $\left(\mathrm{ETR}_{\mathrm{I}}\right) . \mathrm{W}_{80}$ also increased the aboveground and root dry mass by 39 and $0.6 \%$, respectively, and decreased the root/shoot ratio by $40-73 \%$. Under the $\mathrm{W}_{0}$ condition, higher values of $\mathrm{F}_{\mathrm{v}} / \mathrm{F}_{\mathrm{m}}$, $\mathrm{Y}_{\mathrm{II}}, \mathrm{Y}_{\mathrm{I}}, \mathrm{ETR}_{\mathrm{II}}$, and $\mathrm{ETR}_{\mathrm{I}}$ were measured for $\mathrm{F}_{10}$ compared to $\mathrm{F}_{30}$ after $69 \mathrm{~d}$ from emergence. Under the $\mathrm{W}_{80}$ condition, cotton plants with $F_{10}$ showed higher LA, $F_{v} / F_{m}, Y_{I I}, Y_{I}, E_{R}$, and ETR , but there were no significant differences in the photosynthetic pigments compared to $\mathrm{F}_{30}$. Our results suggest that sufficient water in deeper soil layers and the surface application of basal fertilizer could increase photosynthetic activity and efficiency, which promoted aboveground dry mass accumulation and partitioning towards reproductive organs.
\end{abstract}

Additional key words: chlorophyll fluorescence; dry mass; fertigation; gas exchange.

\section{Introduction}

Photosynthesis is one of the most important factors driving crop productivity and is also the main process through which material is recycled and energy transported in ecosystems (Evans 1983). Crop photosynthetic efficiency represents the comprehensive effect of solar radiation, atmospheric $\mathrm{CO}_{2}$ concentration, air temperature, relative humidity, as well as other environmental factors and water-nutrient management measures on crop photosynthetic characteristics (Mayoral et al. 2015). Water and nutrients are the most important factors limiting crop growth (Wang et al. 2015). Thus, modern agricultural research focuses on principles and practices for improvements of the water- and fertilizer-use efficiency

that could enhance the photosynthetic activity of plants in order to achieve higher yields in terms of quality and quantity (Mandal et al. 2006, Yahdjian et al. 2011).

Water deficit might cause a decline in the leaf water potential and stomatal conductance $\left(g_{\mathrm{s}}\right)$ with decreasing net photosynthetic rate $\left(P_{\mathrm{N}}\right)$ in cotton (Lawlor et al. 2002, Flexas et al. 2006), induction of photodamage in PSII of Sophora davidii (Wu et al. 2008), and reduced electron transport rate of PSI of spinach (Jia et al. 2008). The nitrogen nutrient deficiency mainly decreased the accumulation of some ions or compound (e.g., $\mathrm{NO}_{3}^{-}$and $\mathrm{NH}_{4}^{+}$) in roots and leaves of crops and limited moisture absorption (Lopes et al. 2006), the leaf water potential, and

Received 27 May 2016, accepted 17 October 2016, published as online-first 28 November 2016.

${ }^{+}$Corresponding author; phone: +869932058075, fax: + 869932057999, e-mail: Luohonghai79@163.com

Abbreviations: $C_{\mathrm{i}}$ - intercellular $\mathrm{CO}_{2}$ concentration; DAE - days after emergence; DM - dry mass; ETR $\mathrm{II}_{\mathrm{II}}$ - electron transport rate of PSII; ETR - electron transport rate of PSI; $F_{10}$ - surface fertilizer application; $F_{30}$ - deep fertilizer application; FM - fresh mass; $\mathrm{F}_{\mathrm{v}} / \mathrm{F}_{\mathrm{m}}$ - maximal PSII efficiency; $g_{\mathrm{s}}-$ stomatal conductance; LA - leaf area; $P_{\mathrm{N}}$ - net photosynthetic rate; $\mathrm{W}_{80}-$ well watered; $\mathrm{W}_{0}-$ no water; YI - effective quantum yield of PSI; $\mathrm{Y}_{\mathrm{II}}$ - effective quantum yield of PSII; YNA - acceptor side limitation of nonphotochemical quantum yield of PSI; $Y_{\mathrm{ND}}$ - donor side limitation of nonphotochemical quantum yield of PSI; $\mathrm{Y}_{\mathrm{NO}}$ - quantum yield of nonregulated energy dissipation of PSII; $\mathrm{Y}_{\mathrm{NPQ}}$ - quantum yield of regulated energy dissipation of PSII.

Acknowledgements: This study was financially supported by the Research Fund for the National Natural Science Foundation of China (Grant No. 31460325 and U1203283) and the Research Fund for the Doctoral Program of the Xinjiang Production and Construction Corps (2014BB009). 
$g_{\mathrm{s}}$, which caused declining activity of operative enzymes in the Calvin cycle and impaired capacity of carboxylation (Evans 1989) and then reduced $P_{\mathrm{N}}$. In addition, under water- and nitrogen-deficient conditions, increasing rate of nitrogen-nutrient application might improve $g_{\mathrm{s}}$, thereby increasing leaf gas exchange in winter wheat (Livingston et al. 1999). Based on vast studies, examining effects of water and fertilizer supply rate and timing on the photosynthetic activity of crops (Chapin et al. 1980, Clarkson et al. 1980, Evans 1983, Radin et al. 1986, Sinclair et al. 1989), researchers began to focus on the effect of waterfertilizer spatial coupling (water-nutrient application depth in root zone) on crop photosynthesis. The depth of irrigation (at $40 \mathrm{~cm}$ ) and nutrients application (at $30 \mathrm{~cm}$ ) in the root zone limited stomatal opening to reduce $P_{\mathrm{N}}$ of wheat. The deep-layer irrigation mainly generated stress signals (ABA) in the roots above watered depth and caused transport of signals to the crop leaves, limiting stomatal opening (Tardieu et al.1993). Deep fertilizer application decreased the absorption of water and available nutrients in the soil to reduce stomatal opening (Zhang et al. 2006, Shen et al. 2007). Thus, the photosynthetic capacity of leaves was sensitive to the rate and availability of water and nutrients. However, there is little information available on the question whether photosynthetic efficiency or light conversion is affected by water-fertilizer coupling.

Cotton (Gossypium hirsutum L.) is one of the most important fiber-producing crops all over the world. Light and temperature conditions in the Xinjiang region of northwestern China are favorable for cotton growth.

\section{Materials and methods}

Experimental site: The experiment was conducted at a research station of Shihezi University, Xinjiang, in northwestern China $\left(45^{\circ} 19^{\prime} \mathrm{N}, 74^{\circ} 56^{\prime} \mathrm{E}\right)$ from April to October 2015. The maximum and minimum temperatures were 26.9 and $9.4^{\circ} \mathrm{C}$, respectively. The mean precipitation was 34.0, 23.4, 37.2, 11.5, 31.2, 15.4, and $10.5 \mathrm{~mm}$ in April, May, June, July, August, September, and October, respectively. Cotton was grown in polyvinyl chloride (PVC) tubes, $30 \mathrm{~cm}$ in diameter and $120 \mathrm{~cm}$ in height. The bottom of the tube was covered with a wire mesh fine enough to hold the soil while allowing the water to pass through. Clay loam soil collected from the station field was passed through a $2 \mathrm{~mm}$ sieve and packed in the PVC tubes in increments of 0.1 to $1.2 \mathrm{~m}$ and then air-dried. The bulk density of the soil was $1.43 \mathrm{~g} \mathrm{~m}^{-3}$. The soil composition was purple clay loam $(\mathrm{pH}=7.6)$, with $1.45 \mathrm{~g}($ total $\mathrm{N}) \mathrm{kg}^{-1}$, $0.23 \mathrm{~g}\left(\mathrm{P}_{2} \mathrm{O}_{5}\right) \mathrm{kg}^{-1}, 149 \mathrm{~g}$ (total $\left.\mathrm{K}\right) \mathrm{kg}^{-1}$, and $12.5 \mathrm{~g}$ (organic matter) $\mathrm{kg}^{-1}$. Four seeds were sown at a depth of $3 \mathrm{~cm}$ in each tube on 13 May. The seeds were spaced $10 \mathrm{~cm}$ apart in one direction and $20 \mathrm{~cm}$ apart in the other. Drip laterals (Beijing Lvyuan Inc., China) were installed on the top of the tubes, and one emitter per tube was fixed at the center. The top of the tube was covered with a polyethylene film
However, scarcity of water is a major limiting factor for agricultural production in Xinjiang. Consequently, improving the water and nutrient efficiency is indispensable for a yield improvement (Hou et al. 2007, Luo et al. 2014). In our previous studies, irrigation and precipitation before sowing replenished deep-layer water (below $60 \mathrm{~cm}$ ) which was beneficial to root development and distribution in the deeper soil layers and simultaneously improve the water-use efficiency, resulting in the improved cotton yield (Luo et al. 2009, 2014). It can also reduce the inhibitory effect of a root-origin signal (abscisic acid, ABA) on wheat growth, which allows crop to maintain higher water content and physiological activity in leaves (Siddique et al. 1990, Blum et al. 1993, Li et al. 1997). Moreover, basal fertilizer enhances root growth in cotton and absorptive capacity during early growth period, which is conducive for obtaining moisture and nutrient in soil and achieving high photosynthetic efficiency and yield of wheat (Garrido-Lestache et al. 2004, Shen et al. 2011). Based on our previous studies concerning the fertilizer rate (Luo et al. 2015) and mode (Yang et al. 2011), the present study was planned to determine whether the depth of basal fertilizer application can be modified in order to enhance the photosynthetic activity and crop yield through water and fertilizer spatial coupling. Thus, the objectives of this study were (1) to characterize changes in the photosynthetic traits resulting from different depths of the fertilizer application under different deep-layer water conditions and (2) to analyze the physiological mechanisms that lead to the differences in photosynthetic traits and product accumulation.

in order to reduce evaporation. Standard local pest control measures were adopted.

Experimental design: Cotton (Gossypium hirsutum L.) cv. Xinluzao 45 was selected for experiments. Randomized complete block design was employed for four treatments having four replications of each. Twelve tubes per treatment were buried vertically in the field. Two water treatments included (1) deep-layer watering $\left(\mathrm{W}_{80}\right)$, with $0.28 \mathrm{~m}^{3}$ of water (i.e., $80 \pm 5 \%$ of field capacity) per tube at the 80-120 cm deep layer before sowing, or (2) no water added $\left(\mathrm{W}_{0}\right)$, when no water was applied throughout the entire depth of the tube. According to our earlier study (Luo et al. 2015) we applied a fertilizer [more than $2,300 \mathrm{~kg}$ (settled fertilizer) $\mathrm{ha}^{-1}$ ] at two depths, i.e., as a surface application $\left(\mathrm{F}_{10}\right)$ of sufficient basal fertilizer [2.76 $\mathrm{g}(\mathrm{N}), 6.38 \mathrm{~g}\left(\mathrm{P}_{2} \mathrm{O}_{5}\right)$, and $9.36 \mathrm{~g}\left(\mathrm{~K}_{2} \mathrm{O}\right)$ per tube] at the 10-20 cm layer before sowing, and as a deep application $\left(\mathrm{F}_{30}\right)$ of basal fertilizer (of the same amount and content as above) at the $30-40 \mathrm{~cm}$ layer before sowing. Nitrogen was applied at a rate of $0.22 \mathrm{~g} \mathrm{~kg}^{-1}$ (dry soil), with ratios of basal fertilizer to top dressing of $1: 4$; the phosphate and potassium fertilizer application rates were $0.15 \mathrm{~g}\left(\mathrm{P}_{2} \mathrm{O}_{5}\right) \mathrm{kg}^{-1}$ and 
$0.22 \mathrm{~g}\left(\mathrm{~K}_{2} \mathrm{O}\right) \mathrm{kg}^{-1}$ (dry soil), respectively. Nitrogen was applied in the form of $\mathrm{CO}\left(\mathrm{NH}_{2}\right)_{2}(\mathrm{~N}=46 \%)$, and phosphate and potassium were applied in the form of $\mathrm{KH}_{2} \mathrm{PO}_{4}$ $\left(\mathrm{P}_{2} \mathrm{O}_{5}=52 \%, \mathrm{~K}_{2} \mathrm{O}=35 \%\right)$. Each pot was drip-irrigated once every four days. The total amount of water supplied to the plants was $434 \mathrm{~mm}$. At 39, 54, 69, 84, and 99 days after emergence (DAE), functional leaves (fourth fully expanded leaf from the top on the main stem) were selected to measure the photosynthesis, chlorophyll (Chl) contents, Chl fluorescence, and gas exchange of cotton plants. The plants were used also for the determination of root and shoot dry mass (DM).

Photosynthetic pigments and leaf area (LA): After the determination of $\mathrm{Chl}$ fluorescence, all leaves were harvested. Chl $a$ and $b$ were determined spectrophotometrically in selected fresh leaves $(0.1 \mathrm{~g})$, when ground and extracted in $80 \%$ acetone for $96 \mathrm{~h}$. Absorbance was read at 663 and $645 \mathrm{~nm}(U V-2401$, Shimadzu Corporation, Japan) and the Chl content was calculated according to $\mathrm{Li}$ et al. (2000) as follows: $\rho(\mathrm{Chl} a)=12.71 \mathrm{D}_{663}-2.59 \mathrm{D}_{645}$, $\rho(\mathrm{Chl} b)=22.88 \mathrm{D}_{645}-4.67 \mathrm{D}_{663}$, where $\rho(\mathrm{Chl} a)$ or $\rho(\mathrm{Chl}$ $b)$ were the content of the Chl $a$ or $b, \mathrm{D}_{663}$ or $\mathrm{D}_{645}$ were the absorbances read at 663 or $645 \mathrm{~nm}$ by the spectrophotometer. LA was measured using an LI-3000 leaf area meter (LI-COR Inc., NE, USA).

Gas exchange: The net photosynthetic rate $\left(P_{\mathrm{N}}\right)$, stomatal conductance $\left(g_{\mathrm{s}}\right)$, and intercellular $\mathrm{CO}_{2}$ concentration $\left(C_{\mathrm{i}}\right)$ of the leaves were measured between 10:00-12:00 h using a photosynthesis system ( $L i-6400, \mathrm{Li}$-COR Inc., NE, USA) at a light intensity of $1,800 \mu \mathrm{mol}$ (photon) $\mathrm{m}^{-2} \mathrm{~s}^{-1}$ under uniform conditions $\left[25-32^{\circ} \mathrm{C}, 330-350 \mu \mathrm{mol}\left(\mathrm{CO}_{2}\right) \mathrm{mol}^{-1}\right]$.

Chl fluorescence, PSI and PSII: Chl fluorescence was determined on the same leaves employed for the photosynthesis measurements, using a modulated fluorometer

\section{Results}

LA and photosynthetic pigment contents: LA increased with the number of the DAE (Fig. 1). All treatments exhibited similar response patterns during the growth period. The $\mathrm{W}_{80}$ resulted in significantly higher LA compared with the $\mathrm{W}_{0}$; maximum values were observed at 84 DAE under the $\mathrm{W}_{80}$ condition, compared with $69 \mathrm{DAE}$ for the $\mathrm{W}_{0}$ condition. The LA in the $\mathrm{F}_{10}$ was significantly higher than that in the $\mathrm{F}_{30}$. Among all treatments, the highest LA was recorded for the combination of $\mathrm{W}_{80} \mathrm{~F}_{10}$.

From 39 to 84 DAE, Chl $a$ (Fig. $2 A$ ) and Chl $b$ (Fig. $2 B$ ) increased in all treatments but decreased from 84 to $99 \mathrm{DAE}$, and the $\mathrm{Chl} a / b$ ratio (Fig. $2 C$ ) decreased continuously throughout the growing period. Enhanced Chl $a$ and $b$ contents were recorded for $\mathrm{W}_{80}$, but the Chl $a / b$ ratio was lower than that in the $\mathrm{W}_{0}$ (Fig. 2). Significantly higher Chl $a$ and $b$ contents were observed in $\mathrm{F}_{10}$ compared to $\mathrm{F}_{30}$, but the $\mathrm{Chl} a / b$ ratio was lower in the $\mathrm{F}_{10}$
(PAM 100, Walz, Effeltrich, Germany). Initial fluorescence $\left(\mathrm{F}_{0}\right)$ and maximal fluorescence $\left(\mathrm{F}_{\mathrm{m}}\right)$ were measured after a 30-min dark adaptation. The intensity of the saturation pulses, used to determine the maximal fluorescence emission in the presence $\left(\mathrm{F}_{\mathrm{m}}{ }^{\prime}\right)$ and absence $\left(F_{\mathrm{m}}\right)$ of quenching, was $10,000 \mu \mathrm{mol}$ (photon) $\mathrm{m}^{-2} \mathrm{~s}^{-1}, 0.4 \mathrm{~s}$, whereas the actinic light was $1,028 \mu$ mol(photon) $\mathrm{m}^{-2} \mathrm{~s}^{-1}$. After manual balancing of the 830 and $875 \mathrm{~nm}$ signals in the dark, the extents of the difference signals corresponding to $\mathrm{P}_{700}$ fully oxidized by a saturating pulse superimposed on (1) far-red light $\left(\mathrm{P}_{\mathrm{m}}\right)$ or $(2)$ actinic light $\left(\mathrm{P}_{\mathrm{m}}{ }^{\prime}\right)$ were measured. Maximal PSII photochemical efficiency $\left(\mathrm{F}_{\mathrm{v}} / \mathrm{F}_{\mathrm{m}}\right)$, effective quantum yield of PSI and II ( $\mathrm{Y}_{\mathrm{I}}$ and $\left.\mathrm{Y}_{\mathrm{II}}\right)$, quantum yield of nonregulated energy dissipation of PSII $\left(\mathrm{Y}_{\mathrm{NO}}\right)$, quantum yield of regulated energy dissipation of PSII $\left(\mathrm{Y}_{\mathrm{NPQ}}\right)$, donor side limitation of nonphotochemical quantum yield of PSI $\left(\mathrm{Y}_{\mathrm{ND}}\right)$, acceptor side limitation of nonphotochemical quantum yield of PSI $\left(\mathrm{Y}_{\mathrm{NA}}\right)$, electron transport rate of PSI and PSII $\left(E R_{I}\right.$ and ETR II $_{\text {I }}$ ) were calculated using the methods reported by Demmig-Adams (1992) and Kramer (2004).

Dry mass (DM) production, partitioning and root/ shoot ratio: A total of twelve cotton plants (three PVC tubes) were selected from each treatment and cut at the cotyledonary node after the measurement of photosynthesis and $\mathrm{Chl}$ fluorescence. Plants were uprooted from the soil and were separated into leaves, stems, buds, flowers, bolls, and roots. DM was obtained from samples oven-dried at $80^{\circ} \mathrm{C}$.

Statistical analysis: Analysis of variance $(A N O V A)$ was performed using SPSS software v. 16.0. Differences between treatments were considered significant at $P<0.05$ according to least significant difference (LSD) tests. The figures were plotted using software Sigma Plot version 10.0. The data were presented as means \pm SD.

under both the $\mathrm{W}_{0}$ and $\mathrm{W}_{80}$ (Fig. 2C). The highest Chl $a$ and $b$ contents and the lowest $\mathrm{Chl} a / b$ ratio were observed in the $\mathrm{W}_{80} \mathrm{~F}_{10}$.

Changes in gas exchange: The gas-exchange parameters $\left(P_{\mathrm{N}}, g_{\mathrm{s}}\right.$, and $\left.C_{\mathrm{i}}\right)$ increased initially and then declined (Fig. 3). All parameters exhibited similar response patterns to the treatments during the growth period. $P_{\mathrm{N}}$ and $g_{\mathrm{s}}$ of $\mathrm{W}_{80}$ were lower than that of $\mathrm{W}_{0}$ from 39 to $54 \mathrm{DAE}$. In contrast, $P_{\mathrm{N}}$, $g_{\mathrm{s}}$, and $C_{\mathrm{i}}$ in the $\mathrm{W}_{80}$ were higher as compared to that of $\mathrm{W}_{0}$ from 59 to $99 \mathrm{DAE}$. The $\mathrm{W}_{80}$ resulted in peak $P_{\mathrm{N}}, g_{\mathrm{s}}$, and $C_{\mathrm{i}}$ values at $69 \mathrm{DAE}$, compared with $54 \mathrm{DAE}$ in the $\mathrm{W}_{0} . P_{\mathrm{N}}, g_{\mathrm{s}}$, and $C_{\mathrm{i}}$ in the $\mathrm{F}_{10}$ were consistently higher than that in the $\mathrm{F}_{30}$ under both the $\mathrm{W}_{0}$ and $\mathrm{W}_{80}$ conditions during the growth period. In contrast, the highest $P_{\mathrm{N}}, g_{\mathrm{s}}$, and $C_{\mathrm{i}}$ values were observed in the $\mathrm{W}_{80} \mathrm{~F}_{10}$. 


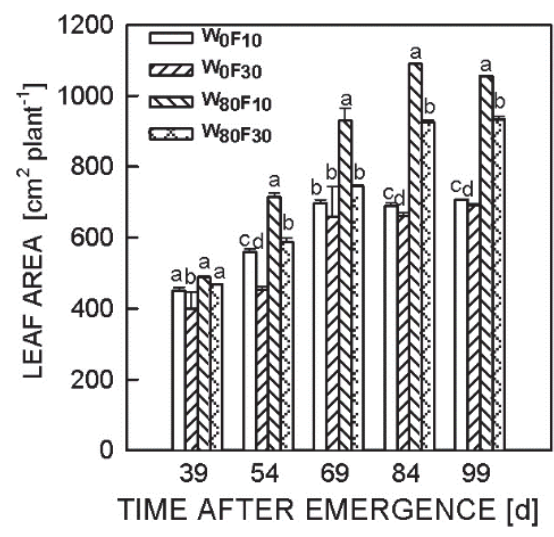

Fig. 1. Changes of leaf area (LA) at watered $\left(\mathrm{W}_{80}\right)$ or nonwatered $\left(\mathrm{W}_{0}\right)$ deep soil layer and base fertilizer surface $\left(\mathrm{F}_{10}\right)$ or deep $\left(\mathrm{F}_{30}\right)$ application with the days after emergence. Bars indicate SD $(n=3)$.Values within columns followed by the same letter are statistically insignificant at the 0.05 level.

Chl fluorescence parameters, PSI and PSII: $\mathrm{F}_{\mathrm{v}} / \mathrm{F}_{\mathrm{m}}$ (Fig. 4), $\mathrm{Y}_{\mathrm{II}}, \mathrm{Y}_{\mathrm{NO}}$, and $\mathrm{ETR}_{\mathrm{II}}$ (Fig. 5A,B,D) increased initially and then decreased. On the contrary, $\mathrm{Y}_{\mathrm{NPQ}}$ decreased initially and then increased (Fig. 5C); all treatments exhibited similar trends during the growth period. Maximum values of $F_{v} / F_{m}, Y_{I I}, Y_{N O}$, and $E_{T R}$ were observed at $69,69,54$, and 54 DAE, respectively, while minimum values of $Y_{\mathrm{NPQ}}$ were observed at 44 DAE. $\mathrm{F}_{\mathrm{v}} / \mathrm{F}_{\mathrm{m}}$, $\mathrm{Y}_{\mathrm{II}}, \mathrm{Y}_{\mathrm{NO}}$, and ETR $\mathrm{II}$ were higher in the $\mathrm{W}_{80}$ than that of $\mathrm{W}_{0}$, while the $Y_{N P Q}$ values presented the opposite pattern during the growth period. The $\mathrm{F}_{\mathrm{v}} / \mathrm{F}_{\mathrm{m}}, \mathrm{Y}_{\mathrm{II}}, \mathrm{Y}_{\mathrm{NO}}$, and $\mathrm{ETR}_{\mathrm{II}}$ values in the $F_{10}$ were significantly higher than that in the $\mathrm{F}_{30}$, while the $\mathrm{Y}_{\mathrm{NPQ}}$ values presented a controversial pattern. The highest values of $F_{v} / F_{m}, Y_{I I}, Y_{N O}$, and ETR $R_{I I}$ were found in the $\mathrm{W}_{80} \mathrm{~F}_{10}$, while the $\mathrm{Y}_{\mathrm{NPQ}}$ values presented the opposite pattern during the growth period. $\mathrm{Y}_{\mathrm{I}}, \mathrm{Y}_{\mathrm{NA}}$, and ETR $_{\mathrm{I}}$ tended to increase and then decrease (Fig. $5 E-G$ ). $\mathrm{Y}_{\mathrm{I}}$, $\mathrm{Y}_{\mathrm{NA}}$, and $\mathrm{ETR}_{\mathrm{I}}$ showed high values from 54 to $69 \mathrm{DAE}$, but $\mathrm{Y}_{\mathrm{ND}}$ continued to increase slowly in all treatments, regardless of stage (Fig. $5 F$ ). The $\mathrm{Y}_{\mathrm{I}}$ and $\mathrm{ETR}_{\mathrm{I}}$ values in the $\mathrm{W}_{80}$ were higher, but the $\mathrm{Y}_{\mathrm{ND}}$ and $\mathrm{Y}_{\mathrm{NA}}$ values were lower than in the $\mathrm{W}_{0}$ throughout the whole growth period. Over the period from 54 to $99 \mathrm{DAE}, \mathrm{Y}_{\mathrm{I}}, \mathrm{Y}_{\mathrm{ND}}$, and ETR $\mathrm{I}$ were significantly higher, but $Y_{N D}$ and $Y_{N A}$ were lower in $\mathrm{W}_{0} \mathrm{~F}_{10}$ compared to $\mathrm{W}_{0} \mathrm{~F}_{30}$. Maximum values of $\mathrm{Y}_{\mathrm{I}}$ and ETR $_{\mathrm{I}}$ and the lowest values of $\mathrm{Y}_{\mathrm{ND}}$ and $\mathrm{Y}_{\mathrm{NA}}$ were observed in the $\mathrm{W}_{80} \mathrm{~F}_{10}$ treatment throughout the whole growth period.

Root/shoot ratio: Across all stages, the aboveground DM exhibited a rapidly increasing trend, and the belowground DM exhibited a slowly increasing trend (Fig. 6), while the root/shoot ratio tended to increase and then decrease (Fig. 7). The total DM in the $\mathrm{W}_{80}$ treatments increased by $22.4 \%$, the aboveground DM increased by $38.6 \%$, the

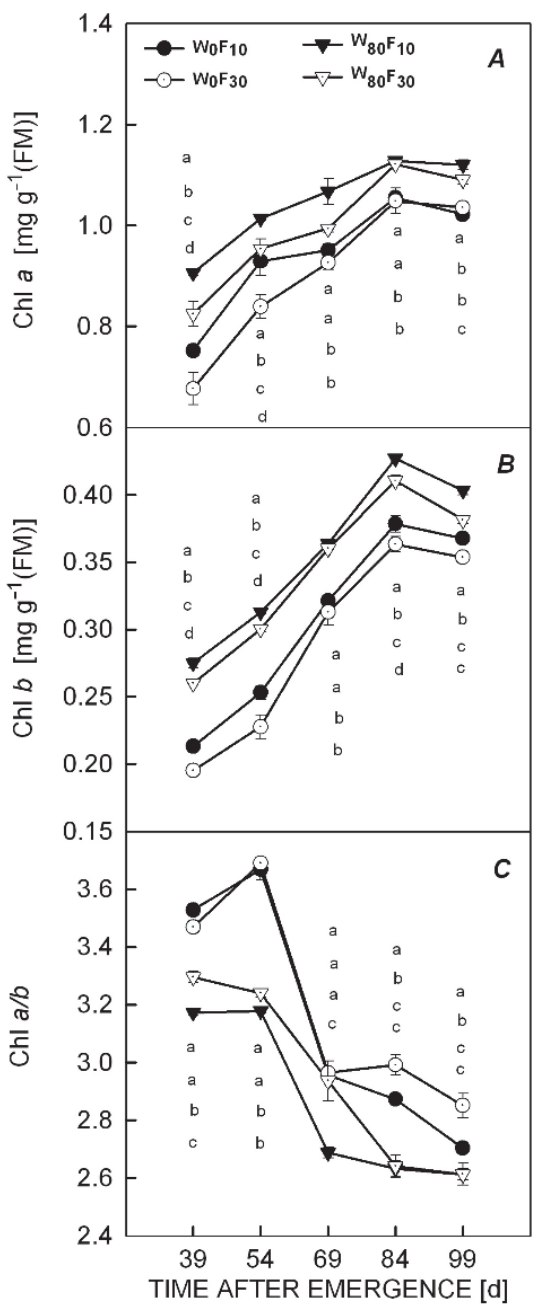

Fig. 2. Changes of chlorophyll (Chl) $a(A)$ and $\mathrm{Chl} b(B)$ contents, and the ratio $\mathrm{Chl} a / b(C)$, in leaf at watered $\left(\mathrm{W}_{80}\right)$ or nonwatered $\left(\mathrm{W}_{0}\right)$ deep soil layer and base fertilizer surface $\left(\mathrm{F}_{10}\right)$ or deep $\left(\mathrm{F}_{30}\right)$ application with the days after emergence. Bars indicate SD $(n=3)$.Values within columns followed by the same letter are statistically insignificant at the 0.05 level.

belowground DM increased by $0.6 \%$, and the root/shoot ratio decreased by $39.5-72.5 \%$ compared with the $\mathrm{W}_{0}$ $\mathrm{W}_{0} \mathrm{~F}_{10}$ increased the total DM by $14.9 \%$, the aboveground DM by $26.6 \%$, and the belowground DM by $3.4 \%$, while the root/shoot ratio decreased by $0.03-22.8 \%$ in comparison with $\mathrm{W}_{0} \mathrm{~F}_{30}$. In the case of $\mathrm{W}_{80} \mathrm{~F}_{10}$, total $\mathrm{DM}$ increased by $5.5 \%$, the belowground DM increased by $5.8 \%$, and the root/shoot ratio increased by $16.3-88.3 \%$ as compared to $\mathrm{W}_{80} \mathrm{~F}_{30}$. However, there was no significant difference in the aboveground DM during the growth period. In the $\mathrm{W}_{80} \mathrm{~F}_{10}$, the total DM, aboveground DM, and belowground DM increased by $2.0-33.6 \%, 0.1-57.0 \%$, and $1.8-6.0 \%$, respectively, and the root/shoot ratio decreased by $6-58.2 \%$ compared with the other treatments. 
DM partitioning: Throughout the whole growth period, the stem and leaf DM increased rapidly from 69 to 99 DAE, while the DM of the reproductive organs increased rapidly from 84 to $99 \mathrm{DAE}$ in all treatments (Fig. 6). In the $\mathrm{W}_{80}$, the DM of the leaf, stem, and reproductive organs were $29.7,31.6$, and $48.1 \%$ higher, respectively, than the corresponding values in the $\mathrm{W}_{0}$ treatments (Fig. 6). Under $\mathrm{W}_{80}$ condition, $\mathrm{F}_{10}$ decreased leaf and stem DM by 12.3 and $7.7 \%$, respectively, while the DM of the reproductive organs increased by $11.9 \%$ in comparison to the

\section{Discussion}

Higher photosynthetic capacity (per unit of leaf area or photosynthetic pigments or leaf gas exchange) plays an important role in yield improvement of plants (van Kooten et al. 1990, Li et al. 2003) and is significantly affected by the water and fertilizer application rate, application modes, and stage of growth (Wang et al. 1999, DaMatta et al. 2002, Flexas et al. 2006, Makoto et al. 2007). Our study showed that changes in $P_{\mathrm{N}}$ were accompanied by changes in $g_{\mathrm{s}}$. Compared to $\mathrm{W}_{0}$, the peak of $P_{\mathrm{N}}$ was delayed in the $\mathrm{W}_{80}$ treatment and appeared at $69 \mathrm{DAE}$, and $P_{\mathrm{N}}$ and $g_{\mathrm{s}}$ in $\mathrm{W}_{80}$ were higher than that in $\mathrm{W}_{0}$ after that peak (Fig. 3). However, $P_{\mathrm{N}}, g_{\mathrm{s}}$, and $C_{\mathrm{i}}$ in $\mathrm{F}_{10}$ under $\mathrm{W}_{80}$ condition were the highest in comparison to other treatments after 54 DAE. It indicated that $\mathrm{W}_{80} \mathrm{~F}_{10}$ could promote the $g_{\mathrm{s}}$-stimulated beneficial effect on leaf gas exchange during the whole growth stage. Many studies have shown that $g_{\mathrm{s}}$ has a positive relation with the soil water content (Chen et al. 2015, Luo et al. 2016). Our early research revealed that deep-layer water resulted in relatively higher root surface area and the root vigor in middle-deep soil layer $(40-50 \mathrm{~cm})$ that increased the use of soil moisture and nutrients in the deep soil layer. However, surface fertilizer application increased relatively the distribution of the root system in soil layer above $20 \mathrm{~cm}$ that was beneficial to reach and absorb water from irrigation (Li et al. 2009), thereby increasing leaf water potential and $g_{\mathrm{s}}$ (Luo et al. 2009). It increased $\mathrm{CO}_{2}$ availability at the mesophyll level (Ball et al. 1994, Rouhi et al. 2007) and ensured a higher $P_{\mathrm{N}}$. It is possible that $\mathrm{W}_{80} \mathrm{~F}_{10}$ could better coordinate a relationship among nutrients, moisture, and root in soil profile, declining the water-nutrient stress on root and formation root signal (ABA), allowing a plant to maintain higher water content and physiological activity in leaves (Siddique et al. 1990, Blum et al. 1993). Lower water and nutrient stress on root could also increase accumulation of some ions or compounds in roots and leaves and then promote moisture absorption (Lopes et al. 2006), leaf water potential, and $g_{\mathrm{s}}$ and increase activity of enzymes in the Calvin cycle promoting carboxylation (Evans 1989). Moreover, $C_{\mathrm{i}}$ in $\mathrm{W}_{80} \mathrm{~F}_{10}$ showed the higher value that was caused by stomatal opening, and the carboxylation efficiency did not decrease, though Rouhi et al. (2007) found that higher $C_{\mathrm{i}}$ decreased the carboxylation efficiency of
$\mathrm{F}_{30}$ treatment. The $\mathrm{W}_{0} \mathrm{~F}_{10}$ increased leaf, stem, and reproductive organ DM by 22.1, 20.3, and 33.1\%, respectively, as compared to $\mathrm{W}_{0} \mathrm{~F}_{30}$. In the case of $\mathrm{W}_{80} \mathrm{~F}_{10}$, the DM of the leaf, stem, and reproductive organs increased by $10.1-34.5$, 15.7-39.1, and 37-82\%, respectively, compared to the $\mathrm{W}_{0} \mathrm{~F}_{10}$ and $\mathrm{W}_{0} \mathrm{~F}_{30}$, while the $\mathrm{DM}$ of the leaf and stem decreased by 14.1 and $8.3 \%$, respectively, and the DM of reproductive organs increased by $12 \%$ compared to $\mathrm{W}_{80} \mathrm{~F}_{30}$.

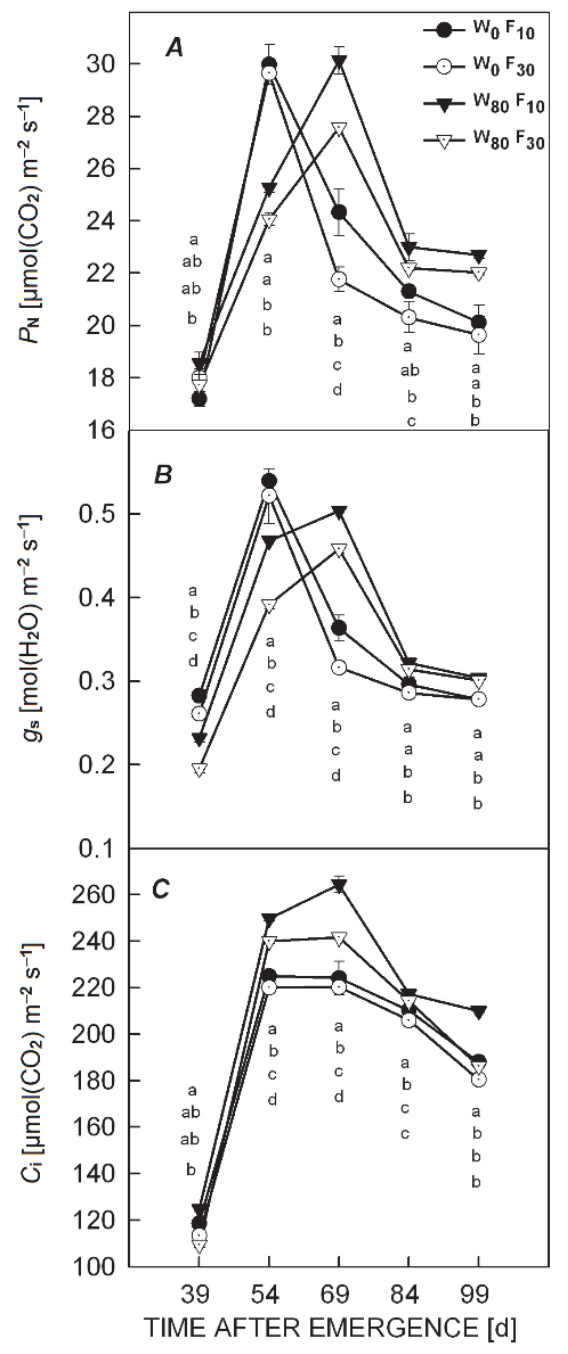

Fig. 3. Changes of net photosynthetic rate $\left(P_{\mathrm{N}}, A\right)$, stomatal conductance $\left(g_{\mathrm{s}}, B\right)$, and intercellular $\mathrm{CO}_{2}$ concentration $\left(C_{\mathrm{i}}, \mathrm{C}\right)$ in leaf at watered $\left(\mathrm{W}_{80}\right)$ or nonwatered $\left(\mathrm{W}_{0}\right)$ deep soil layer and base fertilizer surface $\left(\mathrm{F}_{10}\right)$ or deep $\left(\mathrm{F}_{30}\right)$ application with the days after emergence. Bars indicate SD $(n=3)$. Values within columns followed by the same letter are statistically insignificant at the 0.05 level. 


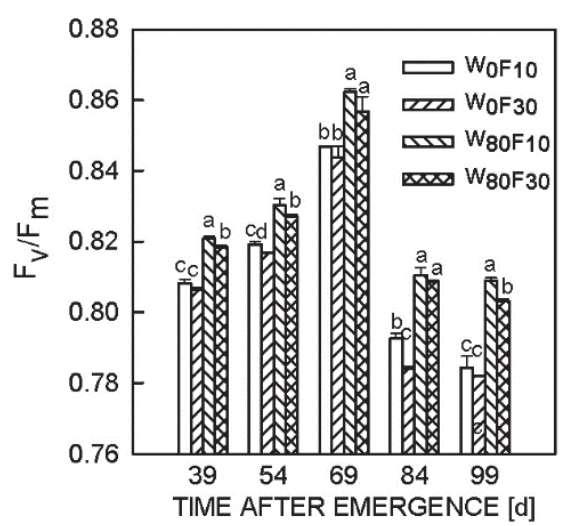

Fig. 4. Changes of maximal PSII photochemical efficiency $\left(\mathrm{F}_{\mathrm{v}} / \mathrm{F}_{\mathrm{m}}\right)$ in leaf at watered $\left(\mathrm{W}_{80}\right)$ or nonwatered $\left(\mathrm{W}_{0}\right)$ deep soil layer and base fertilizer surface $\left(\mathrm{F}_{10}\right)$ or deep $\left(\mathrm{F}_{30}\right)$ application with the days after emergence. Bars indicate $\operatorname{SD}(n=3)$. Values within columns followed by the same letter are statistically insignificant at the 0.05 level.

leaf under the stomatal closure and lower $P_{\mathrm{N}}$. Furthermore, our study also found that $\mathrm{W}_{80} \mathrm{~F}_{10}$ could prolong the duration of photosynthetic functions. A possible reason was that the deep-layer water slowly moved from bottom to top during the experiment (Luo et al. 2014). Adequate availability of water and nutrients also relieved stressinduced senescence of tissues or organs in rice (Hayashi et al. 2013), which prolonged the function of the organs and postponed the $P_{\mathrm{N}}$ peak in $\mathrm{W}_{80} \mathrm{~F}_{10}$. Thus, the $\mathrm{W}_{80} \mathrm{~F}_{10}$ enhanced available water and fertilizer in soil profile which prolonged photosynthesis functioning and increased $g_{\mathrm{s}}$ that promoted $P_{\mathrm{N}}$ and the ability to assimilate carbon in cotton.

Many studies have shown that $\mathrm{Chl}$ fluorescence is sensitive to the amount of water and fertilizer (Jia et al. 2008, Luo et al. 2016), which affects photosynthetic efficiency and the electron transport rate (Jia et al. 2008, Wu et al. 2008). We found that Chl fluorescence and PSI parameters showed the similar tendency in all the treatments during the whole growth stage. Compared to those from other treatments, $\mathrm{W}_{80} \mathrm{~F}_{10}$ resulted in higher $\mathrm{F}_{\mathrm{v}} / \mathrm{F}_{\mathrm{m}}, \mathrm{Y}_{\mathrm{II}}$, $\mathrm{Y}_{\mathrm{I}}, \mathrm{ETR}_{\mathrm{I}}$, and $\mathrm{ETR}_{\mathrm{II}}$ values after $54 \mathrm{DAE}$. It indicated that plants possessed higher activity of the reaction centers and the photoprotective mechanisms of PSII, which promoted photochemical energy conversion and transfer efficiency and the electron transport rate of PSI and PSII. $\mathrm{W}_{80} \mathrm{~F}_{10}$ also promoted the accumulation of nitrogen that resulted in higher Chl $a$ and $b$ contents during the whole growth period (Fig. 2) (Makoto et al. 2007), showing that LHC had a greater ability to capture effective light energy (Jeon et al. 2006). PSII and PSI are very sensitive to environmental stresses (Hayashi et al. 2013, Yi et al. 2016). Adequate moisture availability, when the plants were not simultaneously exposed to high light and high temperature, in particular at midday, decreased the photoinhibition of PSII and PSI and promoted the photochemical efficiency and the electron transport rate of PSII and PSI (Hayashi et al. 2013, Jia et al. 2008, Luo et al. 2016). In addition, $Y_{\mathrm{ND}}$ and
$\mathrm{Y}_{\mathrm{NPQ}}$ in $\mathrm{W}_{80} \mathrm{~F}_{10}$ were lower, indicating that the capacity of PSI electron acceptors were higher or having more PSI electron acceptors. The electron flow from PSII to PSI via the cytochrome $b_{6} / f$ complex generated proton gradient across the thylakoid membrane $(\mathrm{pH})$ to form ATP and balance the ATP and NADPH energy budget (Tikkanen et al. 2014). A possible reason was that adequate moisture and nutrients availability may increased the stressresistance ability of the leaf, that can tolerate intense solar radiations and temperature $\left(>38^{\circ} \mathrm{C}\right)$ to cause over-reduction on the PSI acceptor side leading to PSI photodamage (Munekage et al. 2002, Kono et al. 2014, Tikkanen et al. 2014). Moreover, lower $\mathrm{Y}_{\mathrm{NPQ}}$ and $\mathrm{Y}_{\mathrm{NO}}$ (Fig. 5C,D) values in $\mathrm{W}_{80} \mathrm{~F}_{10}$ further revealed that less energy was dissipated through regulated and nonregulated energy dissipation (Havaux et al. 1991, Lei et al. 2014), while most of the energy was transmitted through linear electron transport, resulting in considerable chemical energy storage (Hendrickson et al. 2004, Takahashi et al. 2013). In consequence, $\mathrm{W}_{80} \mathrm{~F}_{10}$ increased activity of the reaction centers and the photoprotective mechanisms of PSII, promoted photochemical energy conversion and transfer efficiency, and the electron transport rate of PSI and PSII.

Dry mass production is a function of the total light energy intercepted (Monteith et al. 1977, Latiri-Souki et al. 1998). This is also readily affected by the amount of water and fertilizer (Latiri-Souki et al. 1998, Mahajan et al. 2012) and their supply depths (Ayars et al. 1991, Kauer et al. 2013). Our study revealed that total DM and aboveground $\mathrm{DM}$ in $\mathrm{W}_{80}$ were higher, root $\mathrm{DM}$ showed no significant difference, the root/shoot ratio was lower as compared to $\mathrm{W}_{0}$ during the whole growth stage. Under the $\mathrm{W}_{80}$ conditions, the $\mathrm{F}_{10}$ treatment (Figs. 6, 7) exhibited the highest total DM and aboveground DM, the lowest underground DM and the root/shoot ratio compared to other three treatments throughout the whole growth stage. It indicated that $\mathrm{W}_{80} \mathrm{~F}_{10}$ increased photosynthate partitioning to aerial parts of cotton plants. Thus, $\mathrm{W}_{80} \mathrm{~F}_{10}$ provided adequate available water and nutrients and increased the root absorption that promoted photosynthetic capacity (per unit of leaf area or photosynthetic pigments), increased the leaf gas exchange and photochemical energy conversion and use efficiency and enhanced $\mathrm{CO}_{2}$ fixation in leaves (Hendrickson et al. 2004, Takahashi et al. 2013), producing large amounts of photosynthates. Moreover, cotton plants could obtain adequate water by a small root system under $\mathrm{W}_{80} \mathrm{~F}_{10}$, and the root growth of cotton mainly occurred before 69 DAE (Hu et al. 2009). Thus, it was beneficial for the accumulation of photosynthates in the aerial parts of the cotton plants after 69 DAE. Hence, $\mathrm{W}_{80} \mathrm{~F}_{10}$ promoted the accumulation of $\mathrm{DM}$ in aerial parts of cotton plants.

The total DM increases with increasing water supply; the effect is smaller under sufficient water conditions than that under drought conditions, where applied $\mathrm{N}$ doubled the total DM (Lawlor et al. 1981, Giunta et al. 1993, LatiriSouki et al. 1998). Partial irrigation with adequate water 


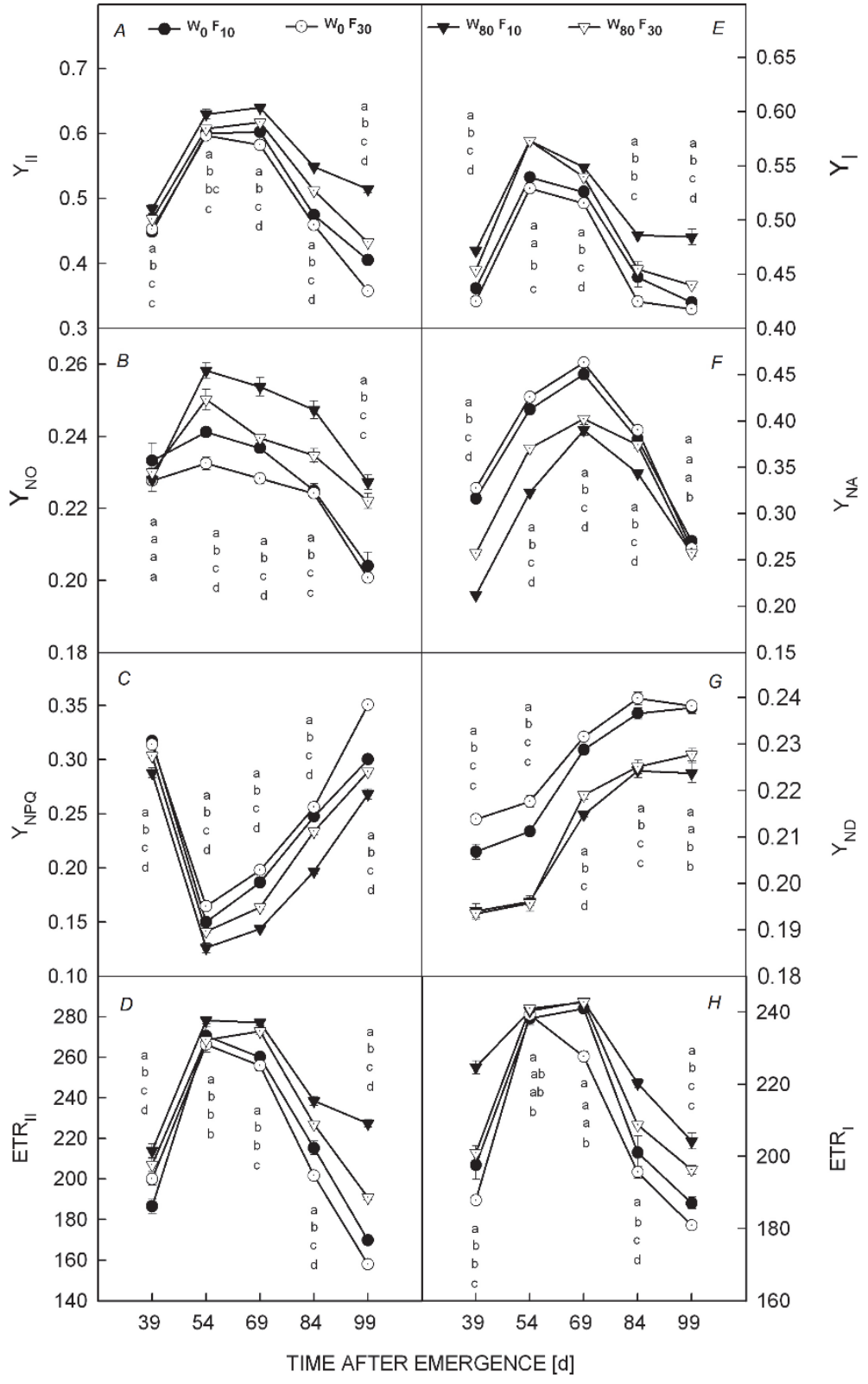

Fig. 5. Changes of effective quantum yield of PSII (Y $\left.\mathrm{Y}_{\mathrm{II}}, A\right)$, quantum yield of nonregulated energy dissipation of PSII ( $\left.\mathrm{Y}_{\mathrm{NO}}, B\right)$, quantum yield of regulated energy dissipation of PSII ( $\mathrm{Y}_{\mathrm{NPQ}}, C$ ), electron transport rate of PSII (ETR $\mathrm{EII}_{1} D$ ), effective quantum yield of PSI $\left(\mathrm{Y}_{\mathrm{I}}, E\right)$, donor side limitation of nonphotochemical quantum yield of PSI (YND, $F$ ) and acceptor side limitation of nonphotochemical quantum yield of PSI ( $\left.\mathrm{Y}_{\mathrm{NA}}, G\right)$, and electron transport rate of PSI $\left(\mathrm{ETR}_{\mathrm{I}}, H\right)$ in leaf at watered $\left(\mathrm{W}_{80}\right)$ or non-watered $\left(\mathrm{W}_{0}\right)$ deep soil layer and base fertilizer surface $\left(\mathrm{F}_{10}\right)$ or deep $\left(\mathrm{F}_{30}\right)$ application with the days after emergence. Bars indicate $\operatorname{SD}(n=3)$. Values within columns followed by the same letter are statistically insignificant at the 0.05 level.

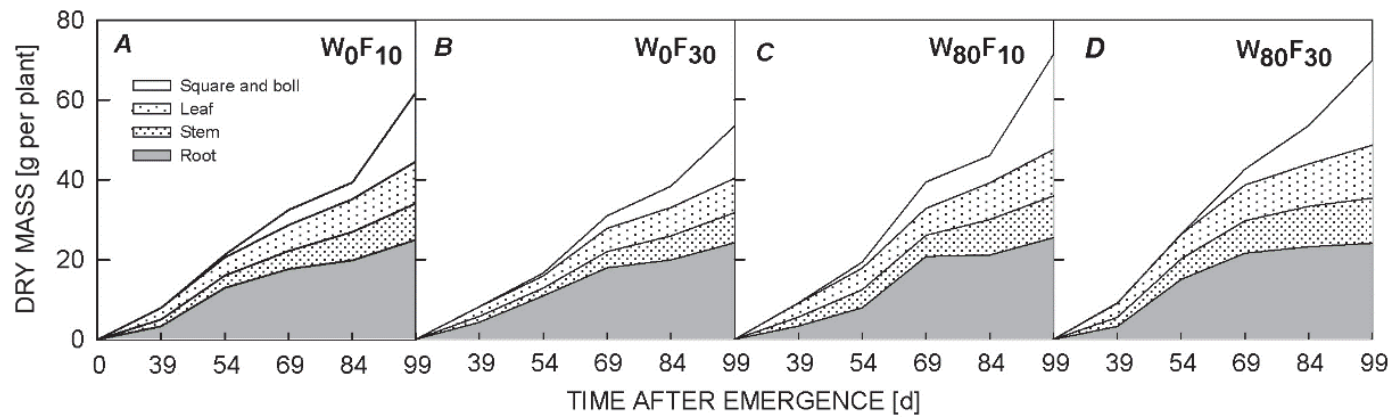

Fig. 6. Change in productive organ, leaf and stem and root dry mass $(A$ : no deep layer water and base fertilizer surface application treatment; $B$ : no deep layer water and base fertilizer deep application treatment; $C$ : deep layer water and base fertilizer surface application treatment; $D$ : deep layer water and base fertilizer deep application treatment) production of cotton at watered (W $\left.\mathrm{W}_{80}\right)$ or nonwatered $\left(\mathrm{W}_{0}\right)$ deep soil layer and base fertilizer surface $\left(\mathrm{F}_{10}\right)$ or deep $\left(\mathrm{F}_{30}\right)$ application with the days after emergence. 
and fertilization supply in the maize root zone reduced the total DM (Kirda et al. 2004, Liang et al. 2006). In addition, the DM accumulation in different organs exhibited significant differences at different growth stages (Tang et al. 2003, Bange et al. 2004). Our results showed that $\mathrm{W}_{80}$ partitioned the most of DM to the aerial part of cotton plants including leaves, stem, and reproductive organs compared to $\mathrm{W}_{0}$. Under the $\mathrm{W}_{80}$ conditions, the $\mathrm{F}_{10}$

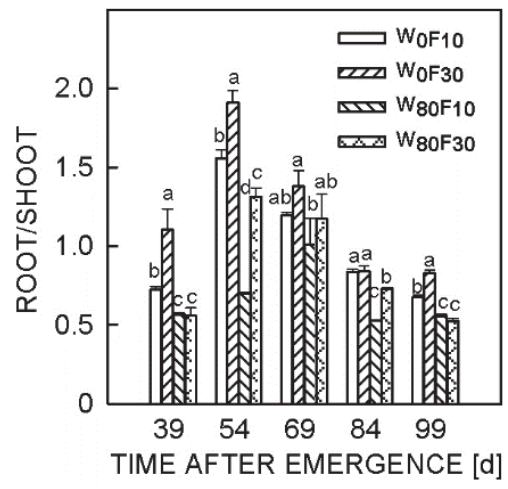

Fig. 7. Change in root shoot ratio of cotton at watered $\left(\mathrm{W}_{80}\right)$ or nonwatered $\left(\mathrm{W}_{0}\right)$ deep soil layer and base fertilizer surface $\left(\mathrm{F}_{10}\right)$ or deep $\left(\mathrm{F}_{30}\right)$ application with the days after emergence. Bars indicate $\mathrm{SD}(n=3)$. Values within columns followed by the same letter are statistically insignificant at the 0.05 level.

\section{References}

Ayars J.E., Hutmacher R.B., Vail S.S. et al.: Cotton response to nonuniform and varying depths of irrigation. - Agr. Water Manage. 19: 151-166, 1991.

Ball M.C., Butterworth, J.A., Roden, J.S. et al.: Applications of chlorophyll fluorescence to forest ecology. - Aust. J. Plant Physiol. 22: 311-319, 1994.

Bange M.P., Milroy S.P.: Growth and dry matter partitioning of diverse cotton genotypes. - Field Crop. Res. 87: 73-87, 2004.

Blum A., Johnson J.W.: Wheat cultivars respond differently to a drying top soil and a possible non-hydraulic root signal. - J. Exp. Bot. 44: 1149-1153, 1993.

Chapin F.S.: The mineral nutrition of wild plants. - Annu. Rev. Ecol. Syst. 11: 233-260, 1980.

Chen X., Hao M.D.: Low contribution of photosynthesis and water-use efficiency to improvement of grain yield in Chinese wheat. - Photosynthetica 53: 519-526, 2015.

Clarkson D.T., Hanson J.B.: The mineral nutrition of higher plants. - Annu. Rev. Plant Physiol. 31: 239-298, 1980.

DaMatta F.M., Loos R.A., Silva E.A. et al.: Effects of soil water deficit and nitrogen nutrition on water relations and photosynthesis of pot-grown Coffea canephora Pierre. - Trees 16: 555-558, 2002.

Demmig-Adams B., Adams W.W.: Carotenoid composition in sun and shade leaves of plants with different life forms. - Plant Cell Environ. 15: 411-419, 1992.

Evans J.R.: Nitrogen and photosynthesis in flag leaf of wheat (Triticum aestivum L.). - Plant Physiol. 72: 297-302, 1983.

Evans J.R.: Photosynthesis and nitrogen relationships in leaves of $\mathrm{C}_{3}$ plants. - Oecologia 78: 9-19, 1989.

Flexas J., Ribas-Carbó M., Bota J. et al.: Decreased Rubisco activity during water stress is not induced by decreased relative promoted a large amount of the aboveground DM partitioning to the reproductive organs compared to other treatments after 84 DAE (Fig. 6). Our results indicated that $\mathrm{W}_{80} \mathrm{~F}_{10}$ enhanced accumulation of $\mathrm{DM}$ in the aerial parts of cotton plants including vegetative and reproductive organs, and promoted the greater aboveground (leaf and stem) DM partitioning to reproductive organs (square and boll), which was in accordance with the result concerning deep-layer water (Luo et al. 2014), base fertilizer application (Yang et al. 2011), and adequate water and nutrients (Radin et al. 1992) that were conducive to the DM accumulation and partitioning to reproductive organs.

Conclusion: Among the treatments in this study, $\mathrm{W}_{80} \mathrm{~F}_{10}$ extended the duration of photosynthetic functions and exhibited the highest LA, photosynthetic pigment contents, gas exchange, and the activity of the photosystems and photochemical energy conversion efficiency after 69 DAE, which caused accumulation of aboveground and reproductive organs (square and boll) $\mathrm{DM}$ in $\mathrm{W}_{80} \mathrm{~F}_{10}$. In summary, the synchronous improvement of photosynthetic capacity and the increase in the photosynthetic efficiency resulting from sufficient water in deeper soil layers and basal fertilizer applied at surface depth were the main reasons for the increase in cotton dry mass and allocation to reproductive organs.

water content but related to conditions of low stomatal conductance and chloroplast $\mathrm{CO}_{2}$ concentration. - New Phytol. 172: 73-82, 2006.

Garrido-Lestache E., López-Bellido R.J., López-Bellido L.: Effect of $\mathrm{N}$ rate, timing and splitting and $\mathrm{N}$ type on breadmaking quality in hard red spring wheat under rainfed Mediterranean conditions. - Field Crop. Res. 85: 213-236, 2004.

Giunta F, Motzo R, Deidda M.: Effect of drought on yield and yield components of durum wheat and triticale in a Mediterranean environment. - Field Crop. Res. 33: 399-409, 1993.

Havaux M., Greppin H., Strasser R.J.: Functioning of photosystems I and II in pea leaves exposed to heat stress in the presence or absence of light. - Planta 186: 88-98, 1991.

Hayashi M., Hayashi T., Kuno C. et al.: Enhanced nitrogen uptake and photosynthesis of rice grown with deep and permanent irrigation method: possible mechanism for chalky grain reduction. - Plant Prod. Sci. 16: 309-316, 2013.

Hendrickson L, Furbank R T, Chow W S.: A simple alternative approach to assessing the fate of absorbed light energy using chlorophyll fluorescence. - Photosynth. Res. 82: 73-81, 2004.

Hou Z.A., Li P.F., Li B.G. et al.: Effects of fertigation scheme on $\mathrm{N}$ uptake and $\mathrm{N}$ use efficiency in cotton. - Plant Soil 290: 115126, 2007.

Hu X.T., Chen H., Wang J. et al.: Effects of soil water content on cotton root growth and distribution under mulched drip irrigation. - Acta. Agron. Sin. 8: 709-716, 2009.

Jeon M.W., Ali M.B., Hahn E.J. et al.: Photosynthetic pigments, morphology and leaf gas exchange during ex vitro acclimatization of micropropagated CAM Doritaenopsis plantlets under relative humidity and air temperature. - Environ. Exp. Bot. 55: 183-194, 2006. 
Jia H, Oguchi R., Hope A.B. et al.: Differential effects of severe water stress on linear and cyclic electron fluxes through Photosystem $\mathrm{I}$ in spinach leaf discs in $\mathrm{CO}_{2}$-enriched air. Planta 228: 803-812, 2008.

Kauer K., Kõlli R., Viiralt R. et al.: Effect of cut plant residue management and fertilization on the dry-matter yield of swards and on carbon content of soil. - Commun. Soil Sci. Plan. 44: 205-218, 2013.

Kirda C., Cetin M., Dasgan Y. et al.: Yield response of greenhouse grown tomato to partial root drying and conventional deficit irrigation. - Agr. Water Manage. 69: 191-201, 2004.

Kono M., Noguchi K., Terashima I.: Roles of the cyclic electron flow around PSI (CEF-PSI) and $\mathrm{O}_{2}$-dependent alternative pathways in regulation of the photosynthetic electron flow in short-term fluctuating light in Arabidopsis thaliana. - Plant Cell Physiol. 55: 990-1004, 2014.

Kramer D.M., Johnson G., Kiirats O. et al.: New fluorescence parameters for the determination of $\mathrm{Q}(\mathrm{A})$ redox state and excitation energy fluxes. - Photosynth. Res. 79: 209-218, 2004.

Latiri-Souki K., Nortcliff S., Lawlor D.W.: Nitrogen fertilizer can increase dry matter, grain production and radiation and water use efficiencies for durum wheat under semi-arid conditions. - Eur. J. Agron. 9: 21-34, 1998.

Lawlor D.W., Day W., Johnston A.E. et al.: Growth of spring barley under drought: crop development, photosynthesis, drymatter accumulation and nutrient content. - J. Agr. Sci. 96: 167-186, 1981.

Lawlor D.W., Cornic G..: Photosynthetic carbon assimilation and associated metabolism in relation to water deficit in higher plants. - Plant Cell Environ. 25: 275-294, 2002.

Lei Y., Zheng Y., Dai K. et al.: Different responses of photosystem I and photosystem II in three tropical oilseed crops exposed to chilling stress and subsequent recovery. Trees 28: 923-933, 2014.

Li F.M., Guo A.H., Luo M.: [Effect of water supply from deep soil on dry matter production of winter wheat.] - Chin. J. Appl. Ecol. 8: 575-579, 1997. [In Chinese]

Li H.S.: [Principles and Techniques of Plant Physiological Experiment.] Pp. 119-120. Higher Education Press, Beijing 2000. [In Chinese]

Li K.F., Zhang F.C., Qi Y.L.: [Effects of water and fertility spatial coupling in root zone soil of winter wheat on root growth and activity.] - Agr. Res. Arid Areas 3: 12, 2009. [In Chinese]

Li X.G., Meng Q.W., Jiang G.Q. et al.: The susceptibility of cucumber and sweet pepper to chilling under low irradiance is related to energy dissipation and water-water cycle. Photosynthetica 41: 259-265, 2003.

Liang J.H., Li F.S., Tang M. et al.: [Effects of alternate partial root-zone irrigation on water and nitrogen utilization of potgrown sweet corn.] - Trans. Chin. Soc. Agric. Eng. 22: 68-72, 2006. [In Chinese]

Livingston N.J., Guy R.D., Sun Z.J. et al.: The effects of nitrogen stress on the stable carbon isotope composition, productivity and water use efficiency of white spruce (Picea glauca (Moench) Voss) seedlings. - Plant Cell Environ. 22: 281-289, 1999.

Lopes M.S., Araus J.L.: Nitrogen source and water regime effects on durum wheat photosynthesis and stable carbon and nitrogen isotope composition. - Physiol. Plantarum 126: 435-445, 2006.

Luo H.H., Tao X.P., Hu Y.Y. et al.: Response of cotton root growth and yield to root restriction under various water and nitrogen regimes. - J. Plant Nutr. Soil Sci. 178: 384-392, 2015.
Luo H.H., Zhang H.Z., Du M.W. et al.: [Regulation effect of water storage in deeper soil layers on root physiological characteristics and leaf photosynthetic traits of cotton with drip irrigation under mulch.] - Chin. J. Appl. Ecol. 6: 1337-1345, 2009. [In Chinese]

Luo H.H., Zhang H.Z., Han H.Y. et al.: Effects of water storage in deeper soil layers on growth, yield, and water productivity of cotton (Gossypium hirsutum L.) in arid areas of northwestern China. - Irrig. Drain. 63: 59-70, 2014.

Luo H.H., Zhang Y.L., Zhang W.F.: Effects of water stress and rewatering on photosynthesis, root activity, and yield of cotton with drip irrigation under mulch. - Photosynthetica 54: 65-73, 2016.

Mahajan G., Chauhan B.S., Timsina J. et al.: Crop performance and water- and nitrogen-use efficiencies in dry-seeded rice in response to irrigation and fertilizer amounts in northwest India. - Field Crop. Res. 134: 59-70, 2012.

Makoto K., Koike T.: Effects of nitrogen supply on photosynthetic and anatomical changes in current-year needles of Pinus koraiensis seedlings grown under two irradiances. Photosynthetica 45: 99-104, 2007.

Mandal K.G., Hati K.M., Misra A.K. et al.: Assessment of irrigation and nutrient effects on growth, yield and water use efficiency of Indian mustard in central India. - Agr. Water Manage. 85: 279-286, 2006.

Mayoral C., Calama R., Sánchez-González M. et al.: Modelling the influence of light, water and temperature on photosynthesis in young trees of mixed Mediterranean forests. - New Forest. 46: 485-506, 2015.

Monteith J.L., Moss C.J.: Climate and the efficiency of crop production in Britain. - Philos. T. R. Soc. B. 281: 277-294, 1977.

Munekage Y., Hojo M., Meurer J. et al.: PGR5 is involved in cyclic electron flow around photosystem I and is essential for photoprotection in Arabidopsis. - Cell 110: 361-371, 2002.

Radin J.W., Eidenbock M.P.: Carbon accumulation during photosynthesis in leaves of nitrogen- and phosphorus-stressed cotton. - Plant Physiol. 82: 869-871, 1986.

Radin J.W., Reaves L.L., Mauney J.R. et al.: Yield enhancement in cotton by frequent irrigations during fruiting. - Agron. J. 84: 551-557, 1992.

Rouhi V., Samson R., Lemeur R. et al.: Photosynthetic gas exchange characteristics in three different almond species during drought stress and subsequent recovery. - Environ. Exp. Bot. 59: 117-129, 2007.

Shen Y.F., Li S.Q., Shao M.A.: [Effects of spatial coupling of watering and fertilization on winter wheat photosynthetic characteristics and grain yield.] - Chin. J. Appl. Ecol. 18: 22562262, 2007. [In Chinese]

Shen Y.F., LI S.Q.: [Effects of the spatial coupling of water and fertilizer on the chlorophyll fluorescence parameters of winter wheat leaves.] - Agron. Sci. China 10: 1923-1931, 2011. [In Chinese]

Siddique K.H.M., Belford R.K., Tennant D.: Root: shoot ratios of old and modern, tall and semi-dwarf wheat in a Mediterranean environment. - Plant Soil 121: 89-98, 1990.

Sinclair T.R., Horie T.: Leaf nitrogen, photosynthesis, and crop radiation use efficiency: a review. - Crop Sci. 29: 90-98, 1989.

Takahashi H., Clowez S., Wollman F.A. et al.: Cyclic electron flow is redox-controlled but independent of state transition. Nat. Commun. 4: 1-8, 2013.

Tang X., Tian C., Lu Z.: Relationship between the spread quantity of nitrogenous fertilizer and the accumulated sunshine requirement of cotton in its growing stages. - Arid Zone Res. 
20: 226-229, 2003.

Tardieu F., Davies W.J.: Integration of hydraulic and chemical signaling in the control of stomatal conductance and water status of droughted plants. - Plant Cell Environ. 16: 341-349, 1993.

Tikkanen M., Mekala N.R, Aro E.M.: Photosystem II photoinhibition-repair cycle protects Photosystem I from irreversible damage. - BBA-Bioenergetics 1837: 210-215, 2014.

van Kooten O., Snel J.F.: The use of chlorophyll fluorescence nomenclature in plant stress physiology. - Photosynth. Res. 25: 147-150, 1990.

Wang J.Y., Gong W., Bao X.L. et al.: [Coupling effects of water and fertilizer on diurnal variation of photosynthetic of Zanthoxylum bungeanum maxim seed leaf.] - Acta Ecol. Sin. 36: 1321-1330, 2015. [In Chinese]

Wang T.C., Li F.M., Wang J. et al.: [Influence of water supply and phosphorus application in different depth on photosynthetic efficiency, dry matter partitioning and water use efficiency of spring wheat.] - Acta Phytoecol. Sin. 23: 177185, 1999. [In Chinese]
Wu F.Z., Bao W.K., Li F.L. et al.: Effects of water stress and nitrogen supply on leaf gas exchange and fluorescence parameters of Sophora davidii seedlings. - Photosynthetica 46: 40-48, 2008.

Yahdjian L., Gherardi L., Sala O.E.: Nitrogen limitation in aridsubhumid ecosystems: a meta-analysis of fertilization studies. - J. Arid Environ. 75: 675-680, 2011.

Yang G.Z., Tang H.Y., Nie Y.C., Zhang X.L.: Responses of cotton growth, yield, and biomass to nitrogen split application ratio. - Eur. J. Agron. 35: 164-170, 2011.

Yi X.P., Zhang Y.L., Yao H.S. et al.: Rapid recovery of photosynthetic rate following soil water deficit and re-watering in cotton plants (Gossypium herbaceum L.) is related to the stability of the photosystems. - J. Plant Physiol. 194: 23-34, 2016.

Zhang Y.Z., Zhang Q.Y., Sun F.F. et al.: [Effect of water and fertilizer interaction on photosynthetic characteristics of winter wheat.] - Agr. Res. Arid Areas 24: 57-60, 2006. [In Chinese] 